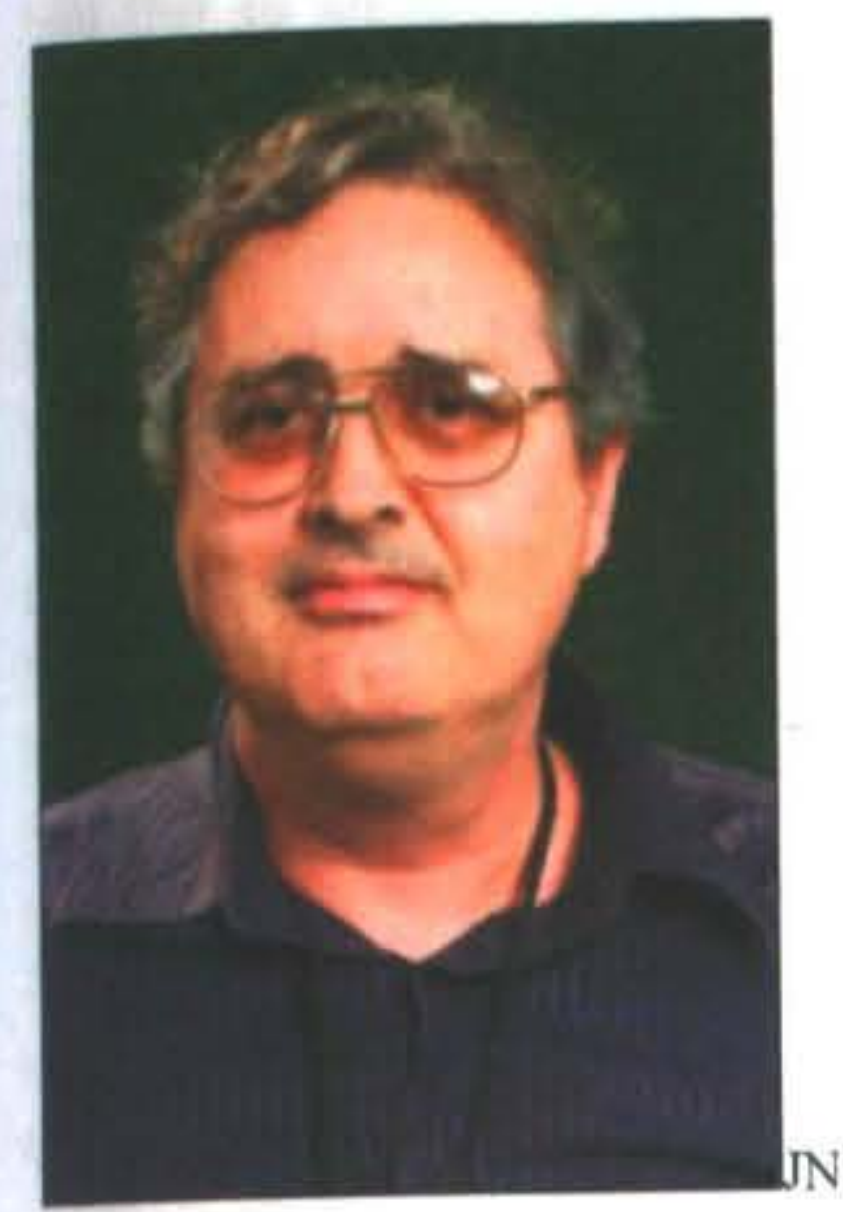

\title{
AUSTRALIAN AND NEW \\ ZEALAND LABOUR \\ MARKETS: SOME \\ SIMILARITIES AND \\ DIFFERENCES
}

\author{
James Newell \\ Monitoring and Evaluation Research \\ Associates Ltd \\ Paul Callister \\ Institute of Policy Studies \\ Victoria University of Wellington
}

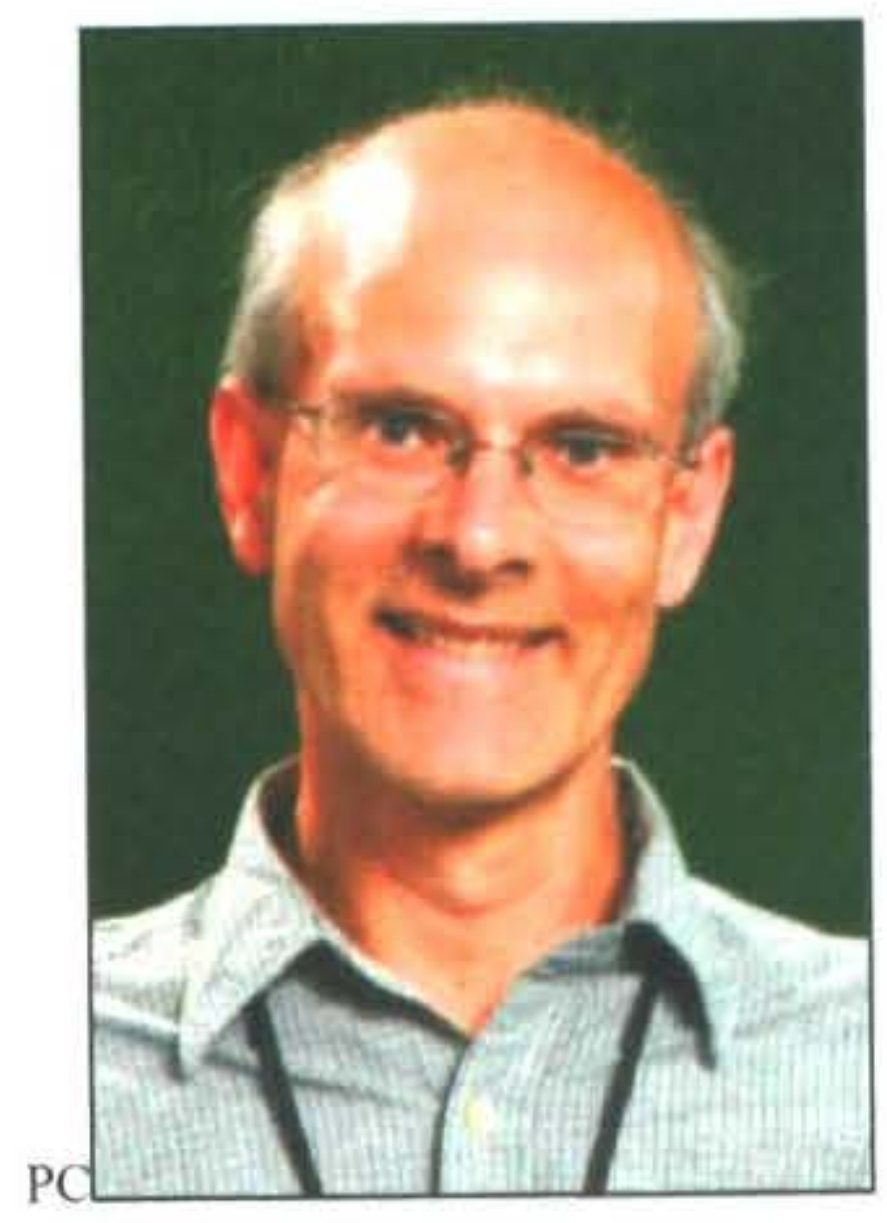

\section{Abstract}

There is much media attention given to New Zealand workers migrating to Australia. Less attention has been given to directly comparing the two labour markets. We use Australian and New Zealand census and labour force survey data to build a 2006/2008 centred comparison of labour market attributes and recent trends in both countries. Key areas considered include: how did the restructuring of the New Zealand economy in the 1980s/early 1990s affect the relative rates of prime-aged male employment in New Zealand as compared to Australia; has there been the same growth in employment of women on both sides of the Tasman: how does the timing of retirement by Australians compare with that of New Zealand residents; how similar are our overall occupational patterns; are young New Zealand born tradespeople proportionately more concentrated in the Australian workforce than in New Zealand; is the occupational structure of Australia resident Maori similar to that of other Australian resident; and how does the balance of extended metropolitan and other labour market catchment types compare? A 2006 Australasian comparative labour market geography developed using the Coombes algorithm as implemented by Newell and Papps 2001 is introduced as a common framework for the comparative study of Australia and New Zealand subnational labour markets.

\section{Introduction}

In recent years the media have highlighted differences between Australia and New Zealand in areas such as wages, taxes and overall standard of living. Given this media interest, one might expect there to be more extensive comparative study of the labour market and other characteristics of the two societies. Arguably this is not the case.

Much of the focus of previous trans-Tasman studies has been directed at understanding and explaining transTasman population flows. Carmichael (1993) brought together results from a major study of trans-Tasman migration trends and possible causes. This study was carried out by a trans-Tasman research team supported jointly by the New Zealand Department of Labour and Australian Bureau of Immigration Research. Poot (1995) considers whether New Zealand can be treated as a state of Australia in the study of inter-state and crossTasman migration. However, more recently there has been a greater focus on labour market comparisons. Brosnan et al (1992) used household labour force (LFS) data to compare Australia and New Zealand. Grimes (2004) compared the changes in industry composition of Australia and New Zealand using 1985 industry (and other) statistics for New Zealand and the Australian States. Haig (2004) compared age trends in the trades workforce of the two countries using 1991 to 2001 census derived occupational statistics. Abhayaratna and Lattimore (2006) examined Australia's labour force participation rates in relation to a range of countries, including New Zealand. This report particularly highlighted job losses for Australian prime aged males ( 25 to 54 years) while showing strong growth in female employment.

This paper examines some of the similarities and differences between the labour market characteristics of Australia and New Zealand This work is a preliminary and prerequisite to a better understanding of the characteristics of "New Zealanders" resident in Australia. These "ex-pat kiwis" are an important piece of the jigsaw of an internationally mobile New Zealand population. The New Zealand resident population experiences regular and highly variable permanent and temporary flows offshore, notably with its Australian neighbour.

Led by the statistical agencies of the two countries, there has been much development of common standards for 
assembling labour market statistics. A common standard for industry classification was established in 1993 and a standard for the measurement of occupational status in 2006. However, classifications applied to many other aspects of working life are incompatible or only partially compatible.

As well as grappling with problems of reconciling the statistical standards of the two countries, the paper also explores a common way of describing the local labour market spatial structures within each country, using 2006 census sourced statistics on recent travel to work behaviour for each country.

\section{Data and Methods}

The perspective adopted in this study is a demographic age and gender based picture of labour supply and the proportion of any age and gender group engaged in work (referred to as the employment rate).

We report on results from the census and labour force surveys for the two countries. Underlying the findings is research to reconcile classifications and standards used in labour market statistics in the two countries.

However, any combination of results from the labour force survey and census opens up problems of crosscomparability of LFS and census labour market statistics. Suffice to say that the labour force survey and the population census can produce quite different estimates of the rates, especially of small probability, local and marginal labour market phenomena as noted in a paper presented to the previous LEW conference and others (for details of that analysis and discussion, refer to Baines et al 2005, 2006).

Monthly labour force survey results for Australia were averaged to a quarterly mean and combined with quarterly results from the New Zealand household labour force survey (HLFS). Since the definitions of full and part time work used in the two surveys are different, total employment was used as a measure of labour force size. Quarterly results for each survey were annualised seasonally adjusted by averaging the last four quarters to date to an annual moving average figure for the year ending on each quarter. This figure was compared with the corresponding average for the four quarters of the previous year. The seasonally adjusted annual rate of change for the year to the current quarter was then the average of the last four quarters compared with average for the four quarters of the previous year

\section{Results}

\section{Overall Trends in Numbers of Jobs}

The annualised employment growth rate results provide an overview of the long term trends in the two labour markets (Figure 1). Between the December 1987 and June 1989 employment in the New Zealand economy collapsed at a time of moderately high growth in jobs in the Australian economy. For the two years from March 1990 and March 1992 employment in the Australian economy steadily dropped reaching a low point of negative employment growth. Over part of that time the New Zealand labour market was in recovery mode arriving at a rate of employment growth equivalent to that of Australia again by March 1991 before adopting the same downward course as the Australian economy.

For the years from March 1991 until the September quarter of 1997 the rate of change in jobs in Australia and New Zealand tracked each other closely. From then the labour markets of both countries have fluctuated within a range, typically one side of the Tasman being out of sync with the direction of change in employment growth rates on the other side of the Tasman.

Figure 1: Annual percent rate of change in employed persons in Australia and New Zealand 1988 to 2008

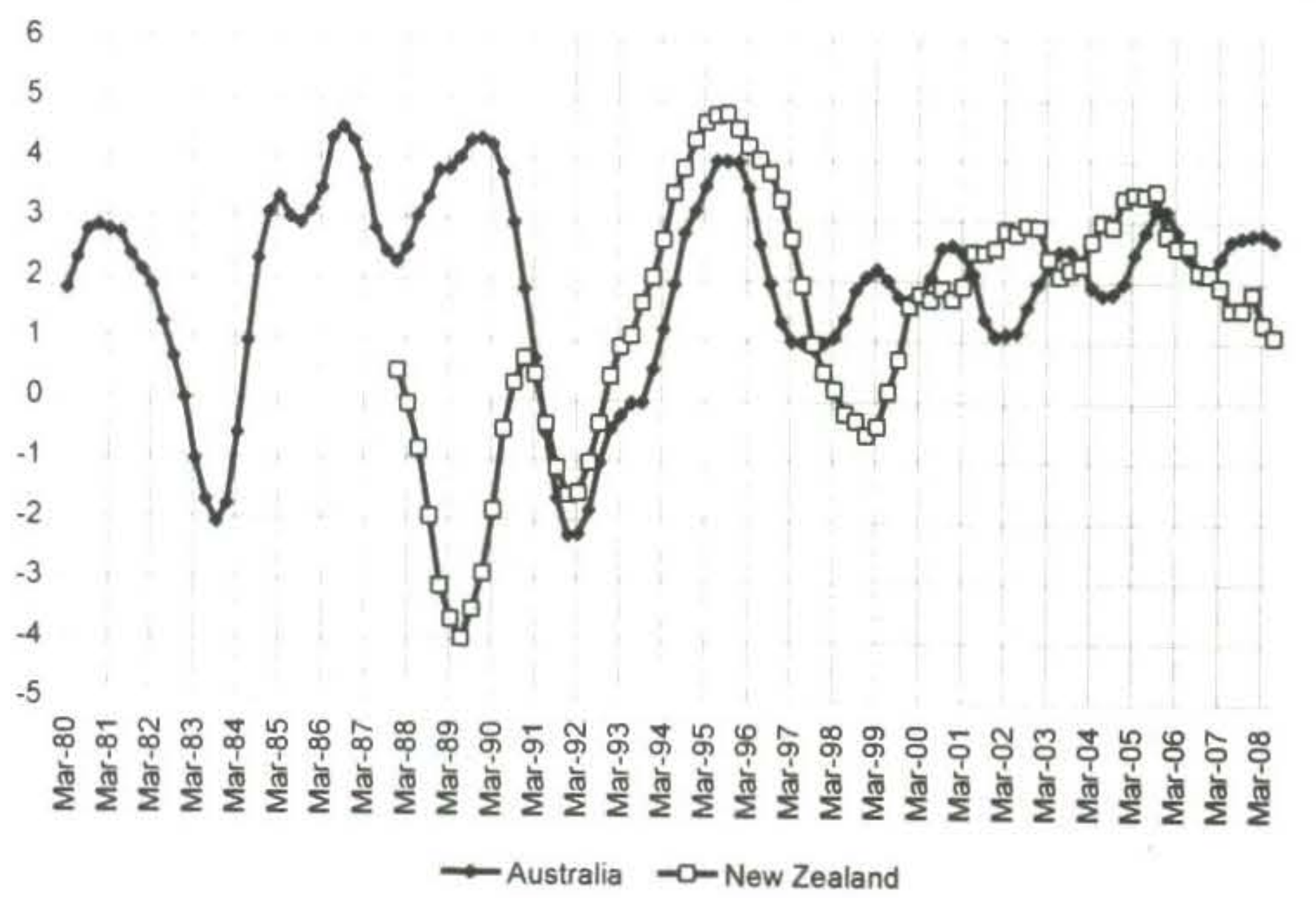




\section{Trends in employment rates}

To compare employment rates in the two countries it is useful to focus on those parts of the population aged fifteen years and over who are below retirement age. To reduce the effect of changing and differing retiree population size relative to other population segments, employment rates for those aged 15 to 60 years are used.

Analysis of New Zealand household labour force survey showed a sharp drop in the employment rate of those aged 15 to 60 years in the labour force between June 1986 and the June 1989. This brought New Zealand employment rates down to those of Australia. Over the period since, overall employment rates of those in New Zealand and Australia have tracked upwards with New Zealand employment rates generally higher than those for Australia.

Australia and New Zealand employment rates have diverged in some areas and converged in others over the last 20 years as shown in Table 1 (labour force survey results). The employment rate for the June 1986 quarter was $58.2 \%$ for 15 to 19 year old New Zealanders compared to only $49.9 \%$ of Australians. Strikingly, employment rates by New Zealanders aged 20 to 24 years was $77.8 \%$ in the June 1986 quarter compared to only $74.3 \%$ in Australia. By the June 2008 quarter the positions were reversed with only $66.8 \%$ of New Zealanders in work compared with $77.1 \%$ in Australia.
Employment rates for the prime work force age range of 35 to 44 years data converged from 8.3 percentage points higher in New Zealand in the June 1986 quarter down to only 2 percentage points by the June 2008 quarter.

At the other extreme of pre-retirement age groups, employment rates for those aged 55 to 59 and 60 to 64 increased in both countries. Between June 1986 and June 2008, margins between the New Zealand and Australian employment rates increased, sharply for those aged 60 to 64 years but also to a lesser extent those aged 65 years and over. By 2008, in the 65 and older age group just over $14 \%$ of New Zealanders were employed compared with just over $9 \%$ of Australians. In the 60-64 age group the differences are also strong with nearly two thirds of New Zealanders employed versus less than half of Australians.

While there is no statutory retirement age in Australia, very few Australians wait until qualifying for the government funded age pension before retiring. The Multi-Purpose Household Survey carried out by the Australian Bureau of Statistics (ABS) from August 2004 to June 2005 found that the average age at retirement of those aged 45 years and over was 60 years, 61.5 years for men and 58.3 years for women. As shown by the New Zealand data, in New Zealand there has been strong growth in the number of people working beyond the age of eligibility for receiving government superannuation.

Figure 2: Employment rate (\%) trend by quarter for persons aged 15 to 60 years in Australia and New Zealand 1988 to 2008
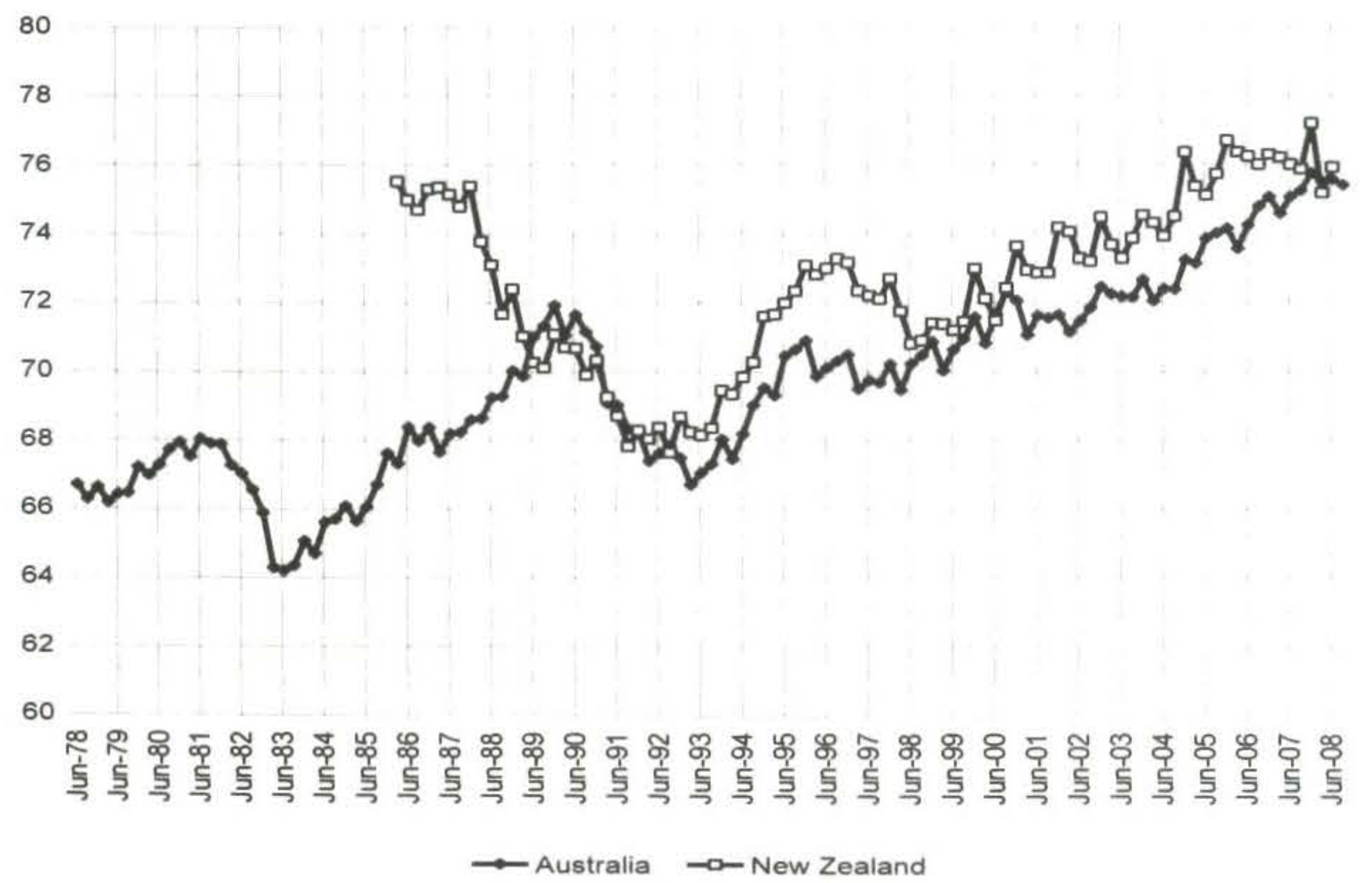
Table 1: Australia and New Zealand employment rates (\%) by age group for selected quarters

\begin{tabular}{|c|c|c|c|c|c|c|c|c|}
\hline \multirow[t]{2}{*}{ Quarter } & Australia & $\mathrm{NZ}$ & Australia & $\mathrm{NZ}$ & Australia & NZ & Australia & $\mathrm{NZ}$ \\
\hline & \multicolumn{2}{|c|}{$15-19 \mathrm{yrs}$} & \multicolumn{2}{|c|}{$20-24 \mathrm{yrs}$} & \multicolumn{2}{|c|}{$25-34$ yrs } & \multicolumn{2}{|c|}{$35-44$ yrs } \\
\hline June 1986 & 49.9 & 58.2 & 74.3 & 77.8 & 72.6 & 75.8 & 75.8 & 84.1 \\
\hline June 1988 & 48.8 & 53.7 & 74.5 & 72.5 & 74.0 & 74.3 & 77.9 & 82.9 \\
\hline \multirow{2}{*}{ June 2008} & 51.6 & 46.2 & 77.1 & 66.8 & 80.1 & 79.8 & 80.4 & 82.4 \\
\hline & \multicolumn{2}{|c|}{$45-54 \mathrm{yrs}$} & \multicolumn{2}{|c|}{$55-59 \mathrm{yrs}$} & \multicolumn{2}{|c|}{$60-64 \mathrm{yrs}$} & \multicolumn{2}{|c|}{$65+y r s$} \\
\hline June 1986 & 69.5 & 79.4 & 51.6 & 65.2 & 27.4 & 32.8 & 5.2 & 8.6 \\
\hline June 1988 & 70.2 & 80.2 & 50.7 & 64.2 & 28.9 & 26.3 & 5.4 & 6.7 \\
\hline June 2008 & 80.8 & 84.9 & 67.0 & 79.3 & 46.7 & 63.6 & 9.2 & 14.4 \\
\hline
\end{tabular}

\section{Gender divergence in employment rates}

Earlier work by the authors had identified a big drop in employment rates for New Zealand males between 1986 and 1991 which had only in part been recovered in subsequent intercensal periods (Callister, 2000; Newell, 2007). This drop in New Zealand male employment rates was accompanied by a small decrease in NZ female employment rates concentrated in labour market entry age groups from 15 to 24 year olds. Subsequent periods yielded steady growth in employment rates by NZ women across a range of age groups. Were these gender based trends in employment rates matched across the Tasman?

Figure 3: Employment rate (\%) for New Zealand and Australian 15 to 60 year old males 1986 to 2008 (Labour Force Surveys)

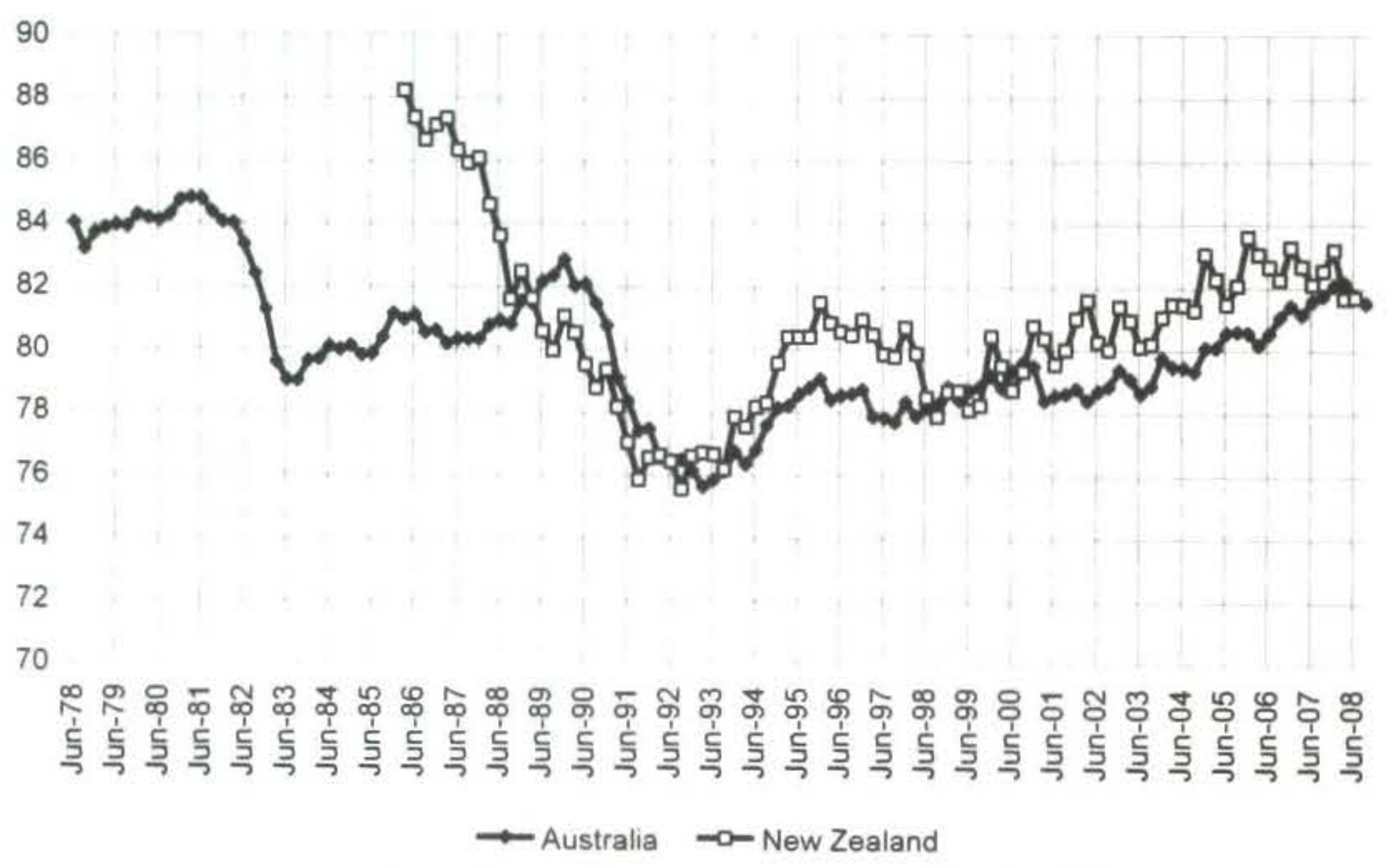

Figure 4: Employment rate (\%) for 15 to 60 year old New Zealand and Australian females 1986 to 2008 (Labour Force Surveys)

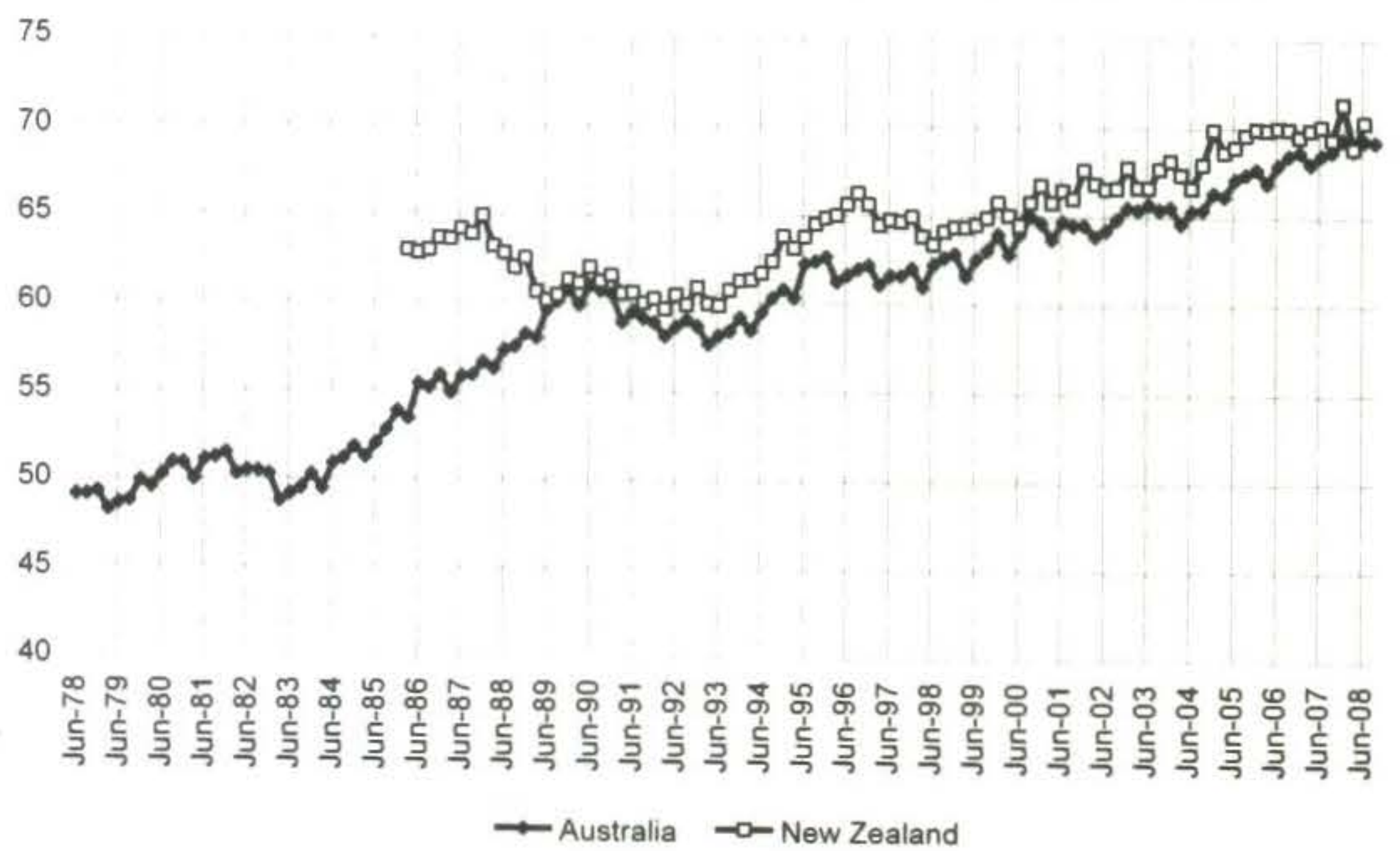


Evidence from the labour force survey charts a picture of steadily decreasing employment rates over time by Australian males, converging with the dramatic drop in employment rates by New Zealand males aged 15 to 60 years during the late 1980's (Figure 3). Employment rates of New Zealand females aged 15 to 60 years show a slight drop to meet lower Australian rates in the late 1980 's after which rates in the two countries track together, but with consistently slightly higher rates for New Zealand females (Figure 4).

\section{Hours worked}

New Zealand and Australia are part of a small group of countries with long hours worked (Messenger, 2004). But how do we compare with Australia? Comparison of hours worked is hindered by different definitions used for part time and full time work in the two countries. Australia defines full time work as those working 35 hours or more whereas New Zealand defines full time work as 30 hours or more. Adding to the difficulties is the limited scope for regrouping the breakdowns by which hours work are coded in Australia census prior to 2006. Australian census data is coded to hour ranges in all census prior to 2006 - one of the ranges is 25 to 34 hours - which precludes regrouping the Australia data to the same full and part time definitions as New Zealand.

Table 2: New Zealand and Australian Hours Worked (\%) by age group in 2006 (Census)

\begin{tabular}{|l|cc|cc|cc|}
\hline & \multicolumn{2}{|c|}{$0-29$ hours } & \multicolumn{2}{c|}{$30-49$ hours } & \multicolumn{2}{c|}{$50+$ hours } \\
& Australia & NZ & Australia & NZ & Australia & NZ \\
\hline $15-19$ yrs & 63.8 & 58.3 & 32.9 & 33.4 & 3.3 & 8.3 \\
$20-24$ yrs & 30.8 & 25.0 & 59.6 & 60.1 & 9.6 & 15.0 \\
$25-29$ yrs & 19.3 & 15.2 & 63.9 & 64.9 & 16.8 & 19.9 \\
$30-34$ yrs & 23.0 & 17.9 & 57.1 & 59.5 & 19.9 & 22.6 \\
$35-39$ yrs & 25.7 & 21.1 & 53.6 & 55.3 & 20.7 & 23.6 \\
$40-44$ yrs & 24.6 & 20.4 & 54.5 & 54.8 & 20.9 & 24.9 \\
$45-49$ yrs & 22.5 & 18.3 & 56.3 & 55.3 & 21.3 & 26.5 \\
$50-54$ yrs & 22.3 & 17.8 & 56.1 & 54.5 & 21.6 & 27.7 \\
$55-59$ yrs & 26.2 & 21.0 & 53.2 & 52.6 & 20.6 & 26.4 \\
$60-64$ yrs & 33.1 & 27.9 & 48.6 & 49.6 & 18.4 & 22.4 \\
$65+$ yrs & 47.6 & 54.6 & 36.2 & 31.3 & 16.2 & 14.1 \\
$15+$ yrs & 27.7 & 24.1 & 54.4 & 53.9 & 18.0 & 22.1 \\
\hline
\end{tabular}

Table 3: New Zealand and Australian hours worked (\%) by age and sex in 2006 (Census)

\begin{tabular}{|l|cc|cc|cc|cc|}
\hline & \multicolumn{4}{|c|}{ Males } & \multicolumn{4}{c|}{ Females } \\
\cline { 2 - 10 } & \multicolumn{2}{|c|}{$0-29$ hours } & \multicolumn{2}{|c|}{$50+$ hours } & \multicolumn{2}{c|}{$0-29$ hours } & \multicolumn{2}{c|}{$50+$ hours } \\
\cline { 2 - 9 } & Australia & NZ & Australia & NZ & Australia & NZ & Australia & NZ \\
\hline $15-19$ yrs & 53.6 & 48.6 & 5.2 & 12.4 & 73.7 & 68.6 & 1.4 & 4.0 \\
$20-24$ yrs & 25.1 & 18.6 & 13.5 & 20.7 & 36.8 & 31.9 & 5.5 & 8.8 \\
$25-29$ yrs & 12.8 & 8.2 & 22.6 & 27.0 & 26.7 & 22.7 & 10.2 & 12.3 \\
$30-34$ yrs & 10.3 & 6.1 & 27.9 & 31.8 & 38.5 & 31.0 & 10.2 & 12.5 \\
$35-39$ yrs & 10.1 & 5.8 & 30.5 & 35.1 & 44.3 & 37.6 & 9.1 & 11.2 \\
$40-44$ yrs & 10.2 & 6.3 & 31.2 & 36.7 & 40.7 & 34.9 & 9.4 & 12.6 \\
$45-49$ yrs & 10.4 & 6.6 & 31.2 & 38.1 & 35.4 & 30.2 & 10.6 & 14.6 \\
$50-54$ yrs & 11.5 & 7.2 & 30.5 & 38.7 & 34.2 & 28.9 & 11.6 & 16.1 \\
$55-59$ yrs & 15.5 & 9.2 & 28.4 & 37.0 & 39.8 & 34.3 & 10.6 & 14.2 \\
$60-64$ yrs & 23.5 & 15.3 & 24.0 & 30.7 & 48.5 & 44.6 & 9.3 & 11.6 \\
$65+$ yrs & 41.1 & 45.4 & 19.5 & 18.5 & 61.2 & 69.7 & 9.3 & 6.9 \\
$15+\mathrm{yrs}$ & 16.6 & 13.2 & 25.6 & 31.3 & 40.5 & 36.2 & 9.1 & 12.0 \\
\hline
\end{tabular}

Using 2006 census data for both countries hours worked by age group, Table 2 shows that New Zealanders of all age groups except those 65 years or older are less likely to work less than 30 hours (part time work) and more likely to work 50 hours or more in 2006. For some reason, Australians aged 65 years or over of either sex are more likely to work 50 hours or more a week than New Zealanders (Table 3).

\section{Industry Structure}

The industry makeup as shown in the surveyed industries in the labour force surveys of the two countries for the March 2008 quarter is shown in Table 4. Industries are grouped to match the breakdowns in the New Zealand household labour force series. The major differences are a much higher proportion engaged in forestry and mining in Australia and less notable is a larger proportion engaged in manufacturing in New Zealand. Australia has a larger share engaged in construction but 
New Zealand a larger proportion engaged in wholesale trade. Australia has a larger proportion employed in retail trade and government administration and defence but New Zealand a greater proportion engaged in accommodation, cafes and restaurants as well as property and business services. Australia has a higher proportion engaged in finance and insurance and double the proportion engaged in electricity, gas and water whereas a higher proportion of New Zealand workers are employed in the health and community services, cultural and recreational services and education.

A $1.8 \%$ per annum, the rate of growth in jobs between March 1989 and March 2008 in New Zealand lagged slightly Australia at $1.9 \%$ per annum (Tables 5 and 6). However growth rate of jobs in Australia (2.5\% per annum) slightly exceeded New Zealand $(2.2 \%$ per annum) in the more recent September 2001 to March 2008 high growth rate part of that period (Table 7). Relativities in the difference in industry level growth rates between New Zealand and Australia were preserved between the longer term trend shown in Table 5 and the more recent trend in Table 7. The notable exceptions were finance and insurance, property and business services and government administration and defence where growth rate of jobs in New Zealand exceeded that of Australia for the more recent period as contrasted with the longer term view. Common to both countries is that the major contribution to new jobs arising from construction, property and business services, retail trade and health and community services. Property and business services led growth in jobs in New Zealand while construction led employment growth in Australia. Both countries saw a major slow down in growth in jobs in education and accommodation, cafes and restaurants in the more recent period since September 2001 than in the longer term March 1989 to September 2008 period.

Grimes (2004) concluded that changes in industry shares between 1985 and 2002 were typical of broader Australasian developments analysed at the level of the state. Grimes also noted that a higher proportion of New Zealand employed were engaged in manufacturing (as shown here) and in agriculture. Similarly, New Zealand is shown to have a greater share than Australia of employment in wholesale trade but less in retail trade, contrasting with Grimes earlier results. The more recent data shows higher growth rates of employment in property and business services, finance and insurance in New Zealand compared with Australia, again differing from Grimes earlier results for an earlier period.

Table 4: New Zealand and Australian full or part time job composition (\%) as at March 2008 (labour force survey)

\begin{tabular}{|l|c|c|c|}
\hline Industry Group & Australia & New Zealand & Difference \\
\hline Agriculture, Forestry and Fishing & 3.2 & 6.8 & -3.6 \\
\hline Mining & 1.3 & 0.0 & 1.3 \\
\hline Manufacturing & 10.5 & 12.2 & -1.7 \\
\hline Electricity, Gas and Water Supply & 0.9 & 0.6 & 0.3 \\
\hline Construction & 9.4 & 8.3 & 1.1 \\
\hline Wholesale Retail Restaurants Hotels & 23.9 & 22.6 & 1.3 \\
\hline Transport and Storage & 4.6 & 3.9 & 0.7 \\
\hline Communication Services & 1.6 & 1.8 & -0.2 \\
\hline Finance and Insurance & 3.7 & 3.2 & 0.5 \\
\hline Property and Business Services & 12.1 & 11.8 & 0.3 \\
\hline Government Community Social Personal Services & 28.7 & 28.1 & 0.6 \\
\hline
\end{tabular}

Table 5: Change in New Zealand and Australian full or part time jobs between March 1989 and March 2008 (labour force survey)

\begin{tabular}{|l|c|c|c|}
\hline \multirow{2}{*}{ Industry } & \multicolumn{3}{|c|}{ March 1989 to March 2008 periods } \\
\cline { 2 - 5 } & \% per annum change in jobs & \multicolumn{2}{c|}{$\%$ Share of total change in jobs } \\
Australia
\end{tabular}


Table 6: Change in New Zealand and Australian full or part time jobs between March 1985 and March 1989 (labour force survey)

\begin{tabular}{|l|cc|cc|}
\hline \multirow{3}{*}{ Industry } & \multicolumn{4}{|c|}{ March 1986 to March 1989 periods } \\
\cline { 2 - 5 } & \multicolumn{2}{|c|}{ \% per annum change in jobs } & \multicolumn{2}{c|}{ \% Share of total change in jobs } \\
& Australia & NZ & Australia & NZ \\
\hline Agriculture, Forestry and Fishing & 1.0 & -1.5 & 1.7 & 8.9 \\
Mining & -2.9 & -35.6 & -1.3 & 5.0 \\
Manufacturing & 1.6 & -7.6 & 8.0 & 85.1 \\
Electricity, Gas and Water Supply & -6.5 & -10.6 & -3.8 & 5.5 \\
Construction & 8.1 & -2.4 & 17.0 & 8.9 \\
Wholesale Retail Restaurants Hotels & 5.0 & -0.9 & 35.3 & 9.6 \\
Transport and Storage & 2.0 & 0.4 & 3.0 & -1.1 \\
Communication Services & 0.3 & -9.0 & 0.2 & 10.5 \\
Finance and Insurance & 5.0 & 1.5 & 6.6 & -3.4 \\
Property and Business Services & 7.2 & 3.2 & 14.6 & -8.8 \\
Government Community Social Personal Services & 2.6 & 1.8 & 18.6 & -25.0 \\
Total All Surveyed Industries & 3.4 & -1.8 & 100.0 & 100.0 \\
\hline
\end{tabular}

Table 7: Change in New Zealand and Australian full or part time jobs between September 2001 and March 2008 (labour force survey)

\begin{tabular}{|l|c|c|c|}
\hline \multirow{2}{*}{ Industry } & \multicolumn{3}{|c|}{ September 2001 to March 2008 periods } \\
\cline { 2 - 4 } & \% per annum change in jobs & \multicolumn{2}{c|}{$\%$ Share of total change in jobs } \\
Australia
\end{tabular}

\section{Occupational Structure}

The introduction of a common occupational classification in 2006 has made comparisons of Australia and New Zealand occupational composition more straightforward. At the highest level of aggregation, some fundamental differences in the New Zealand and Australian occupational makeup can be seen (Table 8). New Zealand has a much higher proportion $(18.2 \%)$ of workers engaged in management occupations than Australia (13.1\%). More detailed analysis of the occupation data at level 2 of the classification shows that chief executives, general managers and legislators make up $3.6 \%$ of New Zealand jobs compared with only $1.0 \%$ of Australian. Specialist Managers make up $7.5 \%$ of New Zealand compared with only $5.8 \%$ of Australian. Farmers and Farm Managers make up 3.3\% of New
Zealand compared with only $2.0 \%$ of Australian jobs. By contrast, Australia has a much higher proportion of jobs $(15.6 \%)$ in clerical and administrative occupations than New Zealand $(12.9 \%)$. Technicians and trades workers are also more heavily represented in Australian jobs (14.7\%) compared with New Zealand (12.9\%). Labourers make up $11.7 \%$ of New Zealand jobs compared with only $10.5 \%$ of Australian jobs.

The gender ratios of New Zealand occupations show higher rates of employment women in traditional male dominated occupations such as "machinery operators and drivers" and "technicians and trades workers" but similar rates of participation of women in management and professional occupations (Table 9). 
Table 8: New Zealand and Australian occupational composition at level 1 of the ANZSCO 2006 classification as at 2006 (census)

\begin{tabular}{|l|cc|cc|}
\hline \multirow{2}{*}{ ANZSCO 2006 level 1 } & \multicolumn{2}{|c|}{ Percentage of Jobs } & \multicolumn{2}{|c|}{ Number of Jobs } \\
& Australia & NZ & Australia & 340,500 \\
Managers & 13.1 & 18.2 & $1,138,400$ & 374,300 \\
Professionals & 20.1 & 20.0 & $1,754,800$ & 241,900 \\
Technicians And Trades Workers & 14.7 & 12.9 & $1,280,200$ & 156,500 \\
Community And Personal Service Workers & 9.1 & 8.4 & 796,200 & 240,800 \\
Clerical And Administrative Workers & 15.6 & 9.9 & $8,358,600$ & 186,100 \\
Sales Workers & 10.2 & 6.1 & 580,400 & 114,300 \\
Machinery Operators And Drivers & 6.7 & 11.7 & 918,200 & 219,000 \\
Labourers & 10.5 & & 218,200 & 112,400 \\
Occupation unidentifiable & & 100 & $8,937,560$ \\
Total & 100 & & $1,985,775$ \\
\hline
\end{tabular}

Table 9: Ratio of male to female workers by occupation at level 1 of the ANZSCO 2006 classification for New Zealand and Australia in 2006 (census)

\begin{tabular}{|l|c|c|}
\hline ANZSCO 2006 level 1 & Australia & NZ \\
\hline Managers & 1.89 & 1.83 \\
Professionals & 0.88 & 0.80 \\
Technicians And Trades Workers & 5.70 & 4.31 \\
Community And Personal Service Workers & 0.45 & 0.43 \\
Clerical And Administrative Workers & 0.30 & 0.27 \\
Sales Workers & 0.62 & 0.67 \\
Machinery Operators And Drivers & 8.61 & 5.20 \\
Labourers & 1.70 & 1.63 \\
Total & 1.17 & 1.12 \\
\hline
\end{tabular}

\section{Employment of New Zealand born and those of Maori Ancestry in Australian Occupations}

Much talk is made of a drain of skilled trades workers and those in some professional groups such as teachers and nurses to Australia. What does the evidence from the 2006 census show? One simple indicator of occupational concentration is the proportion of New Zealand born employed in a particular Australian occupation as compared with the proportion of New Zealand born across all occupations. As shown in Table 10. New Zealand born are concentrated in some key trades occupations. The trade occupations with the highest New Zealand born concentration appear to be those where experience rather than trade certificates are important for job entry.

This is consistent with a lower proportion of New Zealand born in more skilled plumbing and cabinet making occupations and higher representation in roof tillers and floor finishers and other occupations with minimal certification requirements, such as drivers of different kinds, machine operators etc. as listed in Table 11.

Concern is often expressed at a perception of transtasman exodus of New Zealanders with qualifications in teaching, nursing and some other professional occupations. Table 12 shows the concentration of New Zealand born in a range of these occupations in the Australian work force. With some exceptions such as anaesthetists, the proportion of New Zealand born in these occupations is close to or below the proportion of New Zealand born across all occupations.

From the Australian 2006 census it is estimated that there were 43,925 persons of Maori Ancestry employed in Australia in 2006 as compared with 249,435 New Zealand born workers. Those of Maori ancestry tended to be concentrated in a range of semi-skilled or unskilled jobs notably machine operators, drivers etc. as illustrated in Table 13. This is quite a different profile than that of Australian born or Australian residents as a whole. 
Table 10: Percent of Australia resident workers by birthplace for selected trades occupations at level 3 of the ANZSCO 2006 classification (census)

\begin{tabular}{|c|c|c|c|c|c|c|}
\hline \multirow{2}{*}{$\begin{array}{l}\text { Anzsco } 2006 \text { occupation } \\
\text { level } 3\end{array}$} & \multicolumn{3}{|c|}{ Jobs by birthplace } & \multicolumn{3}{|c|}{ Birthplace as $\%$ of occupations } \\
\hline & Australia & $\mathrm{NZ}$ & Total & Australia & $\mathrm{NZ}$ & Other \\
\hline 3333 Roof Tilers & 4,653 & 281 & 5,795 & 82.5 & 5.0 & 12.5 \\
\hline 3331 Glaziers & 5,794 & 302 & 7,337 & 81.0 & 4.2 & 14.8 \\
\hline 3321 Floor Finishers & 6,139 & 337 & 8,501 & 74.2 & 4.1 & 21.7 \\
\hline 3933 Upholsterers & 2,174 & 138 & 3,500 & 63.5 & 4.0 & 32.4 \\
\hline 3322 Painting Trades Workers & 23,258 & 1,445 & 37,867 & 63.3 & 3.9 & 32.7 \\
\hline 3312 Carpenters and Joiners & 67,811 & 3,212 & 87,031 & 79.7 & 3.8 & 16.5 \\
\hline 3332 Plasterers & 18,452 & 898 & 26,742 & 71.0 & 3.5 & 25.6 \\
\hline $\begin{array}{l}3942 \text { Wood Machinists and Other Wood } \\
\text { Trades Workers }\end{array}$ & 4,589 & 185 & 6,297 & 74.8 & 3.0 & 22.2 \\
\hline All Occupations & $6,645,998$ & 249,435 & $9,104,187$ & 74.5 & 2.8 & 22.7 \\
\hline 3941 Cabinetmakers & 17,347 & 561 & 22,448 & 79.0 & 2.6 & 18.4 \\
\hline 3311 Bricklayers and Stonemasons & 17,683 & 607 & 25,620 & 71.2 & 2.4 & 26.4 \\
\hline 3341 Plumbers & 48,090 & 1,263 & 56,703 & 86.8 & 2.3 & 10.9 \\
\hline 3334 Wall and Floor Tilers & 8,460 & 235 & 14,001 & 62.1 & 1.7 & 36.2 \\
\hline
\end{tabular}

Table 11: A selection of occupations with much higher than average proportions of New Zealand born workers at level 3 of the ANZSCO 2006 classification (census)

\begin{tabular}{|l|ccc|ccc|}
\hline Anzsco 2006 occupation & \multicolumn{3}{|c|}{ Jobs by birthplace } & \multicolumn{3}{c|}{ Birthplace as \% of occupations } \\
level 3 & Australia & NZ & Total & Australia & NZ & Other \\
\hline 8217 Structural Steel Construction Workers & 9217 & 1629 & 13678 & 69.3 & 12.2 & 18.5 \\
3612 Shearers & 3666 & 315 & 4175 & 90.8 & 7.8 & 1.4 \\
3991 Boat Builders and Shipwrights & 3884 & 353 & 4974 & 79.6 & 7.2 & 13.1 \\
7122 Drillers, Miners and Shot Firers & 24995 & 2095 & 30283 & 84.6 & 7.1 & 8.4 \\
7213 Forklift Drivers & 27061 & 2379 & 39383 & 70.6 & 6.2 & 23.2 \\
7219 Other Mobile Plant Operators & 5587 & 428 & 7462 & 76.5 & 5.9 & 17.6 \\
4314 Hotel Service Managers & 3426 & 316 & 5437 & 64.2 & 5.9 & 29.9 \\
8313 Meat, Poultry and Seafood Process Workers & 11071 & 933 & 17239 & 66.2 & 5.6 & 28.2 \\
8312 Meat Boners and Slicers, and Slaughterers & 7383 & 488 & 9523 & 79.3 & 5.2 & 15.5 \\
8211 Building and Plumbing Labourers & 30936 & 1996 & 40658 & 78.1 & 5.0 & 16.8 \\
3333 Roof Tilers & 4653 & 281 & 5795 & 82.5 & 5.0 & 12.5 \\
8214 Insulation and Home Improvement Installers & 9558 & 617 & 12957 & 75.6 & 4.9 & 19.5 \\
7121 Crane, Hoist and Lift Operators & 6282 & 403 & 8473 & 76.5 & 4.9 & 18.6 \\
1419 Other Accommodation and Hospitality & 4880 & 331 & 6926 & 71.7 & 4.9 & 23.4 \\
Managers & & & & 82.6 & 4.9 & 12.5 \\
8219 Other Construction and Mining Labourers & 5336 & 315 & 6601 & 71.4 & 4.8 \\
6393 Telemarketers & 7330 & 492 & 10546 & 7.4 & 23.9 \\
2344 Geologists and Geophysicists & 3792 & 287 & 6097 & 62.8 & 4.8 & 32.4 \\
8212 Concreters & 19920 & 1169 & 25779 & 79.7 & 4.7 \\
\hline
\end{tabular}

Table 12: Proportion of New Zealand born workers in a selection of professional occupations in Australia at level 3 of the ANZSCO 2006 classification (census)

\begin{tabular}{|c|c|c|c|c|c|c|}
\hline \multirow{2}{*}{$\begin{array}{l}\text { Anzsco } 2006 \text { occupation } \\
\text { level } 3\end{array}$} & \multicolumn{3}{|c|}{ Jobs by birthplace } & \multicolumn{3}{|c|}{ Birthplace as $\%$ of occupations } \\
\hline & Australia & $\mathrm{NZ}$ & Total & Australia & $\mathrm{NZ}$ & Other \\
\hline 2531 Generalist Medical Practitioners & 17,104 & 590 & 35,454 & 48.9 & 1.7 & 49.4 \\
\hline 2532 Anaesthetists & 1,581 & 97 & 2,728 & 58.6 & 3.6 & 37.8 \\
\hline 2533 Internal Medicine Specialists & 2,053 & 112 & 3,594 & 57.9 & 3.2 & 38.9 \\
\hline 2534 Psychiatrists & 1,174 & 70 & 2,180 & 54.4 & 3.2 & 42.3 \\
\hline 2535 Surgeons & 2,384 & 102 & 3,902 & 61.7 & 2.6 & 35.7 \\
\hline 2539 Other Medical Practitioners & 3,255 & 200 & 5,850 & 56.3 & 3.5 & 40.3 \\
\hline 2541 Midwives & 9,321 & 259 & 12,239 & 77.4 & 2.1 & 20.5 \\
\hline 2542 Nurse Educators and Researchers & 2,692 & 122 & 3,761 & 72.7 & 3.3 & 24.0 \\
\hline 2543 Nurse Managers & 7,978 & 317 & 10,897 & 74.2 & 2.9 & 22.8 \\
\hline 2544 Registered Nurses & 119,154 & 5,478 & 172,567 & 70.6 & 3.2 & 26.1 \\
\hline 2412 Primary School Teachers & 106,547 & 1,595 & 126,054 & 85.9 & 1.3 & 12.8 \\
\hline 2414 Secondary School Teachers & 93,723 & 1,407 & 118,669 & 80.3 & 1.2 & 18.5 \\
\hline 2415 Special Education Teachers & 11,014 & 265 & 13,734 & 81.6 & 2.0 & 16.4 \\
\hline 2421 University Lecturers and Tutors & 20,892 & 836 & 35,594 & 59.4 & 2.4 & 38.3 \\
\hline All Oecupations & $6,645,998$ & 249,435 & $9,104,187$ & 74.5 & 2.8 & 22.7 \\
\hline
\end{tabular}


Table 13: Australian occupations with a high proportion of workers of Maori ancestry at level 3 of the ANZSCO 2006 classification (census)

\begin{tabular}{|c|c|c|c|}
\hline $\begin{array}{l}\text { Anzsco } 2006 \text { occupation } \\
\text { level }\end{array}$ & $\begin{array}{c}\text { Maori } \\
\text { Ancestry }\end{array}$ & Total Jobs & $\begin{array}{l}\% \text { of Maori } \\
\text { Ancestry }\end{array}$ \\
\hline 821 Construction and Mining Labourers & 2,458 & 119,306 & 2.06 \\
\hline 831 Food Process Workers & 1,058 & 56,560 & 1.87 \\
\hline 721 Mobile Plant Operators & 1,656 & 94,141 & 1.76 \\
\hline 741 Storepersons & 1,570 & 96,846 & 1.62 \\
\hline 832 Packers and Product Assemblers & 1,130 & 84,870 & 1.33 \\
\hline 733 Truck Drivers & 1,663 & 130,129 & 1.28 \\
\hline 712 Stationary Plant Operators & 978 & 77,362 & 1.26 \\
\hline 442 Prison and Security Officers & 620 & 51,493 & 1.20 \\
\hline 800 Labourers, nfd & 256 & 22,479 & 1.14 \\
\hline 839 Miscellaneous Factory Process Workers & 607 & 54,371 & 1.12 \\
\hline 361 Animal Attendants and Trainers, and Shearers & 216 & 20,393 & 1.06 \\
\hline 711 Machine Operators & 765 & 84,556 & 0.90 \\
\hline 732 Delivery Drivers & 252 & 31,818 & 0.79 \\
\hline 332 Floor Finishers and Painting Trades Workers & 365 & 46,435 & 0.79 \\
\hline 322 Fabrication Engineering Trades Workers & 541 & 70,936 & 0.76 \\
\hline 333 Glaziers, Plasterers and Tilers & 409 & 54.015 & 0.76 \\
\hline 891 Freight Handlers and Shelf Fillers & 446 & 62,021 & 0.72 \\
\hline Total & 43,925 & $9,104,187$ & 0.48 \\
\hline
\end{tabular}

\section{A Spatial Model of Local Labour Market Catchments of Australasia}

The first part of the paper has been concerned with comparing overall Australia and New Zealand labour markets. What would we see if we tried to map the spatial boundaries that define labour markets areas based on people's behaviour in travelling to work rather than purely on an administrative basis? The following are some preliminary results of such a functional classification of Australia and New Zealand using a standard method for mapping labour markets, the Coombes algorithm (Coombes et al, 1986).

The Coombes algorithm is here replicated using a well tested and documented implementation, that reported in Newell and Papps (2001).
The product of the algorithm is a set of what are best described as highly self-contained labour market "catchments". These catchments are almost exclusively contiguous clusters of the notionally small official statistical spatial units of each country. In the New Zealand analysis the 2006 "statistical area unit" was used and in the Australian case the 2006 "statistical local areas" were used.

The properties of these labour market catchments fall into two extremes. They can be of a reasonable size or be small but compensate for size with a high level of job "self-containment". The measure "job self-containment" refers to the proportion of local residents who work locally and the ratio of non-residents who commute to work within a local catchment area.

Table 14: Usually resident 2006 population estimates of "extended metropolitan" labour market catchments of Australasia identified by analysis of $\mathbf{2 0 0 6}$ census travel to work data from the Australian and New Zealand census

\begin{tabular}{|l|c|l|l|}
\hline \multicolumn{3}{|c|}{ "Extended metropolitan" Labour Market Catchments (LMCs) of Australasia based on 2006 Census travel to work data } \\
\hline ALS LMA06 Interim Name & Population & NZ LMA06 Interim Name \\
\hline Sydney & $4,119,206$ & Greater Central and North Auckland \\
Melbourne & $3,688,731$ & Extended Manukau South Auckland \\
Brisbane & $1,868,152$ & Greater Christchurch & 861,093 \\
Adelaide & $1,216.137$ & Greater Wellington \\
Outer Perth & 784,213 & \\
Central and Metropolitan Perth & 670.047 & \\
Hunter & 538,704 & \\
Gold Coast South & 509,633 & \\
Extended Canberra-Queanbeyan & 384,785 & \\
Balance of Australia & $6,033,474$ & Balance of New Zealand \\
Australia & $19,813.082$ & New Zealand \\
\% of population resident in an "extended & $\mathbf{6 9 . 5 \%}$ & \\
metropolitan" Labour Market Catchment & & \\
\hline
\end{tabular}


The reconciliation of the respective urban and rural geographies is a work in progress, but it appears that a lower proportion of New Zealanders than Australians live in major urban areas. This proposition is suggested by an analysis of the characteristics of the large labour market catchments. Table 14 summarises the attributes of the labour market catchments of each country with a population over 300,000 - which represents an indicative line in the sand between truly large multi-hub metropolitan regions and less intensive provincial urban hubs and other urban and rural labour market catchments of each country.

All other things being equal, it appears likely that New Zealand labour market catchments are smaller / less spatially extended than Australian labour market catchments. On 2006 data, $69.5 \%$ percent of the usually resident population of Australia lived in labour market catchments with of 300,000 or larger. By contrast, it is estimated that $56.7 \%$ of the 2006 New Zealand usually resident population lived in labour market catchments with of 300,000 or larger

\section{Discussion and Conclusions}

Long term trends suggest that prior to the structural reengineering of the New Zealand economy of $1988 / 89$, the differences between participation rates and other characteristics of the New Zealand and Australian labour markets were more pronounced than at any time since.

Since that time, employment and labour force participation rates have converged. This is especially true of the employment rates of New Zealand males which dropped rapidly over a few short years in the mid to late 1980's from a much higher rate than their Australian counterparts. In the period since labour force survey data shows that employment rates of New Zealand males have tracked slightly above those of their Australian counterparts. Gains in female employment rates over the last two decades have been steady in both countries but slightly higher in New Zealand than Australia.

The period of economic restructuring in the $1980 \mathrm{~s} / 90 \mathrm{~s}$ in New Zealand drove a rapid reduction in male employment rates. However, the data from both sides of the Tasman suggest that while the New Zealand industry restructuring might have changed the timing of the decline, more fundamental underlying changes in labour demand (and perhaps supply) were taking place in both Australia and New Zealand leading to more recent convergence in male employment rates.

Yet while we have convergence in some areas, there is divergence in others. The divergence in the employment rates of 60 to 64 year old New Zealanders and Australians is an indicator of differences in retirement patterns of residents of the two countries. In the period since the early 1990's, employment rates of New Zealand males aged 15 to 59 years have usually tracked above those of Australians. Similarly, after a drop in New Zealand female employment rates in the December 1987 to June 1989 period, rates for New Zealand females have tracked with but slightly above those of Australian females.

Another point of difference is in the share of total jobs in and relative growth rates of different industries as measured in the Australia and New Zealand labour force surveys. With the notable exception of the March 1986 to March 1989 period when the number of jobs in New Zealand dropped sharply during a period of modest growth in Australian jobs, rates of change in jobs in the two countries have tracked closely. The September 2001 to March 2008 period saw a high $2.5 \%$ per annum rate of growth of jobs in Australia and a $2.2 \%$ annual growth rate of jobs in New Zealand.

The most marked differences in March 2008 are that New Zealand had a much higher proportion $(6.8 \%)$ than Australia (3.2\%) engaged in "agriculture, forestry and fishing" and this may be related to the slightly higher proportion of New Zealanders $(12.2 \%)$ compared with Australians (10.5\%) engaged in manufacturing.

The recent September 2001 to March 2008 period saw a sharp drop in the proportion engaged in "agriculture, forestry and fishing" in the two countries. New Zealand experienced a sharp drop in manufacturing employment over that period while there was some small growth in manufacturing jobs in Australia. Both countries experienced substantial growth in employment between September 2001 and March 2008 arising from job growth in 'government community social and personal services', 'property and business services', construction and 'wholesale, retail, restaurants and hotels'. In New Zealand growth in jobs in 'wholesale, retail, restaurants and hotels' and property and business services' lead this period of relative boom in the labour market while 'government community social and personal services' dominated Australian job growth.

2006 census data using the ANZSCO classification indicates that New Zealand has a significantly higher proportion engaged in management but also slightly higher proportion engaged in labouring occupations than Australia. Perhaps the difference in managers is a reflection of a larger reliance on small and medium enterprises in New Zealand.

The gender ratios of New Zealand occupations show higher rates of employment women in traditional male dominated occupations such as "machinery operators and drivers" and "technicians and trades workers" but similar rates of participation of women in management and professional occupations.

Much talk is made of a drain of skilled trades and professional skilled workers from New Zealand to Australia. There is mixed evidence for this based on an analysis of the distribution of New Zealand born 
Australians by occupation. There is a lower proportion of New Zealand born in some trades groups such as cabinet makers $(2.6 \%)$, plumbers $(2.3 \%)$ and bricklayers or stonemasons $(2.4 \%)$ compared to all occupations $(2.8 \%)$. Some building occupations such as carpenters and joiners $(3.8 \%)$ glaziers $(4.2 \%)$ and roof tilers $(5 \%)$ are slightly over-represented amongst New Zealand born Australia residents. The highest rates of New Zealand born are amongst some skilled labouring jobs such as "structural steel construction workers (12.2\%) boat builders and shipwrights $(7.2 \%)$ and forklift drivers $(6.2 \%)$. Amongst professional groups the evidence for selective migration of particular occupations is again mixed. It would appear that teachers of all types including secondary school teachers $(1.2 \%)$ and primary school teachers $(1.3 \%)$ have a much lower proportion of New Zealand born than all occupations. University lecturers or tutors $(2.4 \%)$ are more heavily represented but still below the proportions across all occupations. Registered nurses have a slightly higher representation of New Zealand born than average ranging up to $3.6 \%$ for anaesthetists amongst various types of medical related occupations. Overall, the conclusion is that the attraction of the Australian labour market appeals most strongly to skilled and unskilled labourers with only slightly higher appeal than average for some skilled professional or trade occupations. Some professional groups (teachers in particular) are under represented amongst Australian resident New Zealand born. It should be noted that this analysis applies to New Zealand born long term migrants from New Zealand and a different story may applied to those who have more recently gained New Zealand residence prior to migration to Australia.

It is estimated that in 2006 there were 44,000 employed Australian residents of Maori Ancestry compared to only about 250,000 employed New Zealand born Australian residents. Those of Maori ancestry tend to be concentrated in a range of semi-skilled or unskilled occupations such as notably machine operators, drivers etc. mirroring concentration of New Zealand born in these occupations and contrasting with Australian born residents.

New Zealand and Australian populations have a different distribution across different levels of the "settlement hierarchy" represented by large extended multi-hub metropolitan regions at the high end and small self contained rural communities or single industry towns on the other. Using 2006 labour market catchment areas for the two countries defined using the Coombes (1986) algorithm as adapted to New Zealand by Newell and Papps (2001), 69.5\% of the Australian population lived in large extended multi-hub metropolitan regions of 300,000 or more compared with only $56.7 \%$ of New Zealand residents.

\section{Future Work}

Increasing standardisation in labour market statistical classifications is providing the conditions to support in depth comparative study of the operation of the labour markets of the two countries.

The immediate focus of future work in this area by this research programme is on those Australian residents most clearly and easily linked to New Zealand, namely those residents who are New Zealand born and those of Maori Ancestry.

While there are many similarities between the recent labour market histories and current labour market structures of the two countries, the paper has shown there are also some significant differences now and in the recent past. Further work should seek to better understand the factors associated with these and other significant New Zealand - Australia differences.

Better understanding of historical trends in comparative labour market conditions in Australia and New Zealand will help better explain large shifts over time in cross Tasman migration flow rates of resident and returning New Zealanders.

Finally, this paper introduces a common labour market geographical classification as a building block towards a common spatial language for subnational studies across the two countries. These results will be further developed into a common labour market spatial framework identifying labour market catchment types. These types will provide the basis for comparative analysis of labour market and migration / mobility dynamics at a labour market catchment type level.

\section{Acknowledgements}

This research has been funded by the Foundation for Research, Science and Technology through the "Missing Men" programme, a FRST funded programme of research with the long title "Education capital formation, employment, migration, gender, work-life balance and missing men" led by the Institute of Policy Studies, Victoria University of Wellington.

\section{References}

Abhayaratna, J. and Lattimore, R. (2006). Workforce participation rates - How does Australia compare?, Productivity Commission Staff Working Paper, Canberra

Baines, J., Newell, J. and Taylor, N. (2005). Multiple Job Holding : comparison of data from the Household Labour Force Survey and the Census. Working Paper No 12, FRST Research Project TBAX0204 (Revised December 2006) Taylor Baines Associates, Canterbury, New Zealand. 
Baines, J. and Newell, J. (2006). The pitfalls of monitoring minority labour market phenomenon $12^{\text {th }}$ Conference on Labour Employment and Work in New Zealand. Victoria University of Wellington, Wellington, New Zealand.

Brosnan, P., Burgess, J. and Rea, D. (1992). Two ways to skin a cat: government policy and labour market reform in Australia and New Zealand, International Contributions to Labour Studies, 2: $17-44$.

Callister, P. (2000). Living and working in New Zealand: Links between labour market change and household structure, Wellington: Institute of Policy Studies.

Carmichael, G.A.(ed) (1993). Trans-tasman Migration . Trends, Causes and Consequences. Commonwealth of Australia, Bureau of Immigration Research, South Carlton, Victoria Australia.

Coombes, M.G., Green, A.E. and Openshaw, S. (1986). An efficient algorithm to generate official statistical reporting areas: The case of the 1984 travel-to-work areas revision in Britain. Journal of the Operational Research Society, 37, 943-953.

Grimes, A. (2004). New Zealand : A Typical Australasian Economy? Motu Working Paper 0411 Motu Economic and Public Policy Research Trust, Wellington, New Zealand.

Haig, R. (2004). Age Trends in the New Zealand and Australian Trades Workforce $11^{\text {th }}$ Conference on Labour Employment and Work in New Zealand. Victoria University of Wellington, Wellington, New Zealand.
Messenger, J. (2004). Working time and workers' preferences in industrialised countries: Finding the balance, London: Routledge.

Newell, J. and Papps, K., (2001). Identifying functional labour market areas in New Zealand : A reconnaissance study using Travel to Work Data. Occasional Paper2001/6, Department of Labour, Wellington, New Zealand.

Newell, J. (2007). Workforce supply and demand trends and the transition to work of the "baby blip" generation. Presentation to the "Is Young Auckland Working? Youth Pathways to Employment" Held at Massey Albany Campus, $17^{\text {th }}$ August 2007.

Poot, J. (1995). Do Borders Matter? A Model of Interregional Migration in Australasia. Australasian Journal of Regional Studies, 1(2), 159-182.

\section{Authors}

James Newell

Monitoring and Evaluation Research Associates Ltd.

P.O. Box 2445

Wellington

J.Newell@mera.co.nz

Paul Callister

Deputy Director

Institute of Policy Studies

Victoria University of Wellington

P.O. Box 600

Wellington 6140

Paul.Callister@vuw.ac.nz 